\title{
THE HIERARCHY OF ASSOCIATIVITY EQUATIONS FOR n=3 CASE WITH AN METRIC $\eta_{11} \neq 0$
}

\author{
Zhadyranova A.A. ${ }^{1}$, Myrzakul Zh.R. ${ }^{2}$, Myrzakulov K.R. ${ }^{1}$ \\ ${ }^{1}$ L.N. Gumilyov Eurasian National University, Nur-Sultan, Kazakhstan \\ ${ }^{2}$ Nazarbayev University, Nur-Sultan, Kazakhstan
}

\begin{abstract}
This paper describes the hierarchy for $\mathrm{N}=2$ and $\mathrm{n}=3$ case with an metric $\eta_{11} \neq 0$ when $\mathrm{V}_{0}=0$ of associativity equations. The equation of associativity arose from the 2D topological field theory. 2D topological field theory represent the matter sector of topological string theory. These theories covariant before coupling to gravity due to the presence of a nilpotent symmetry and are therefore often referred to as cohomological field theories. We give a description of nonlinear partial differential equations of associativity in $2 \mathrm{D}$ topological field theories as integrable nondiagonalizable weakly nonlinear homogeneous system of hydrodynamic type.

The article discusses nonlinear equations of the third order for a function $f=f(x, t))$ of two independent variables $x$, t. In this work we consider the associativity equation for $\mathrm{n}=3$ case with an a metric $\eta_{11} \neq 0$. The solution of some cases of hierarchy when $\mathrm{N}=2$ and $\mathrm{V}_{0}=0$ equations of associativity illustrated.
\end{abstract}

Keywords: the string theories, the physical fields, the hierarchy of associativity equations.

\author{
Аннотация \\ А.А. Жадыранова ${ }^{1}$, Ж.Р. Мырзакул ${ }^{2}$, K.Р. Мырзакулов ${ }^{l}$ \\ ${ }^{1}$ Евразийский национальный университет имени Н. Гумилева, г.Нур-Султан, Казахстан \\ ${ }^{2}$ Назарбаев Университет, Нур-Султан, Казахстан

\section{ИЕРАРХИЯ УРАВНЕНИЯ АССОЦИАТИВНОСТИ ДЛЯ СЛУЧАЯ $n=3$ С $\eta_{11} \neq 0$ МЕТРИКОЙ}

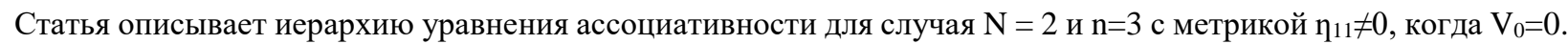
Уравнение ассоциативности возникло из 2D топологической теории поля. 2D топологическая теория поля представляет собой материальный сектор топологической теории струн. Эти теории ковариантны перед связыванием с гравитацией из-за наличия нильпотентной симметрии и поэтому часто называются когомологическими теориями поля. Дано описание нелинейных дифференциальных уравнений в частных производных ассоциативности в 2D топологических теориях поля как интегрируемой недиагонализуемой слабонелинейной однородной системы гидродинамического типа.

В статье рассматриваются нелинейные уравнения третьего порядка для функции $\mathrm{f}=\mathrm{f}(\mathrm{x}, \mathrm{t}))$ двух независимых переменных $\mathrm{x}$, t. В работе рассматривается уравнение ассоциативности для $\mathrm{n}=3$ случая с метрикой $\eta_{11} \neq 0$. Проиллюстрировано решение некоторых случаев иерархии при $\mathrm{N}=2$ и $\mathrm{V}_{0}=0$ уравнения ассоциативности.

Ключевые слова: теория струн, физические поля, иерархия уравнения ассоциативности.

\author{
Аңцдатпа \\ А.А. Жадыранова ${ }^{1}$, Ж.Р. Мырзакул ${ }^{2}$, К.Р.Мырзакулов ${ }^{1}$ \\ ${ }^{1}$ Л.Н. Гумилев атындавы Еуразия ұлттық университеті, Нұр-Сұлтан қу., Қазақстан \\ ${ }^{2}$ Назарбаев университеті, Нур-Султан қ., Қазақсттан
}

$\eta_{11} \neq 0$ МЕТРИКАСЫМЕН $n=3$ ЖАҒДАЙЫ ҮШІН АССОЦИАТИВТІ ТЕНДЕУІНІН ИЕРАРХИЯСЫ

Бұл мақалада $\eta_{11} \neq 0$ метрикасымен $\mathrm{V}_{0}=0$ болғандағы $\mathrm{N}=2$ және $\mathrm{n}=3$ жағдайы үшін ассоциативтілік теңдеуінің иерархиясы қарастырылады. Ассоциативті тендеуі 2D топологиялық өріс теориясынан туындаған. 2D топологиялық өріс теориясы ішектердің топологиялық теориясының материалдық секторы болып табылады. Бұл теориялар нильпотентті симметрияның болуына байланысты гравитациямен байланыстыру алдында ковариантты және сондықтан жиі өрістің когомологиялық теориялары деп аталады. 2D топологиялық теориясында ассоциативтілік теңдеу жүйесінің гидродинамикалық типтегі интегралданатын сызықты емес біртекті жүйе ретінде берілген.

Бұл жұмыста x, t тәуелсіз айнымалыларынан тұратын $\mathrm{f}=\mathrm{f}(\mathrm{x}, \mathrm{t})$ функциясы үшін үшінші ретті сызықты емес теңдеулер талқыланады. Ассоциативтілік теңдеу метрика $\eta_{11} \neq 0$ болғандағы n=3 жағдайы үшін қарастырылады. Ассоциативтілік теңдеулер $\mathrm{N}=2$ және $\mathrm{V}_{0}=0$ иерархиясының бірнеше шешімдері сипатталады.

Түйін сөздер: ішектер теориясы, физикалық өрістер, ассоциативтілік теңдеуінің иерархиясы. 
The physical correlation functions are metric-independent is the consequence of a symmetry of topological quantum field theory which reduces the Hilbert space $\mathrm{H}$ to the space $\mathrm{H}_{\text {phys }}$ of physical states, and causes the stress-tensor $\mathrm{T}_{\alpha \beta}$ to decouple from physical correlation functions [1]. Almost all of the information of the amplitudes can be encoded in the operator algebra of the local physical operators. These coefficients $\mathrm{c}_{\mathrm{ijk}} \mathrm{can}$ be used to formally define the operator algebra of the physical fields

$$
\phi_{i} \times \phi_{k}=\sum_{k} c_{i j}^{k} \phi_{k}
$$

The factorization expansion

$$
\left\langle\phi_{i} \phi_{j} \phi_{k} \phi_{l}\right\rangle_{0}=\sum_{m, n}\left\langle\phi_{i} \phi_{j} \phi_{m}\right\rangle_{0} \eta^{m n}\left\langle\phi_{n} \phi_{k} \phi_{l}\right\rangle_{0}=\sum_{m} c_{i j}^{m} c_{m k l}
$$

This equation states that the four-point amplitude can be obtained by gluing together two three-point functions. This function $\mathrm{F}(\mathrm{t})$ call the free energy of the topological cohomological field theory, plays the role of the generating functional and $\mathrm{F}(\mathrm{t})$ can write

$$
F(t)=\left\langle\exp \left(\sum_{n} t_{n} \int \Phi_{n}\right)\right\rangle
$$

Topological string theory closely resembles the string theories and in particular there are many correspondences with fermionic string theory [1]. To couple the topological field theories to two-dimensional gravity need to modify the ordinary gravity theory, such that it also exhibits a Q-symmetry. This theory is called two-dimensional topological gravity. In topological string theory besides the bosonic moduli $\mathrm{m}_{\mathrm{k}}$, there are also an equal number of anti-commuting moduli $\widehat{\mathrm{m}_{\mathrm{k}}}$, which are their Q-superpartners. An geometric description of such gauge quivalence classes is as the Q-symmetric generalization of Riemann surfaces. The complete amplitudes of topological string theory are given by the integral over $\mathrm{sM}_{\mathrm{g}, \mathrm{s}}$ of a function which, via the identification, represents a volume form on $\mathrm{M}_{\mathrm{g}, \mathrm{s}}$. The integrand is given by the product of the closed forms represented by the matter and gravitational correlators

$$
\left\langle\sigma_{n 1}\left(\phi_{i j}\right) \ldots \sigma_{n s}\left(\phi_{j s}\right)\right\rangle=\int_{s M_{g s}} d m_{k} d \hat{m}_{k}\left\langle\sigma_{n 1} \ldots \sigma_{n s}\right\rangle_{\Sigma(m, \hat{m})}\left\langle\phi_{1} \ldots \phi_{s}\right\rangle_{\Sigma(m, \hat{m})}
$$

For instance, given any Riemann surface I in space-time, we define [2]

$$
\theta_{k, \Sigma}=\int_{\Sigma} \theta_{k(2)}
$$

As in ordinary string theory, the amplitudes of topological strings can be written as integrals over the moduli space $\mathrm{M}_{\mathrm{g}}$ Riemann surfaces [3]. For the partition function $\mathrm{F}$ of a general model with lagrangian [4]

$$
L=L_{0}-\sum_{n, \alpha} t_{n, \alpha} \int \sigma_{n}\left(\theta_{\alpha}\right)
$$

Two dimensional quantum gravity can be formulated as a sum over random surfaces. The geometric picture is that the measure of 2-d topological gravity may be thought of as being fully concentrated on degenerate surfaces [5].

In this paper we shall consider so-called nonlinear partial differential equations of associativity in 2D topological field theories (see [6-8]). The equation of associativity arising originally in two-dimensional topological field theories $[6,8]$ : in general, have the following form:

$$
\frac{\partial^{3} F}{\partial t^{i} \partial t^{j} \partial t^{p}} \eta^{p q} \frac{\partial^{3} F}{\partial t^{q} \partial t^{k} \partial t^{r}}=\frac{\partial^{3} F}{\partial t^{j} \partial t^{k} \partial t^{p}} \eta^{p q} \frac{\partial^{3} F}{\partial t^{i} \partial t^{q} \partial t^{r}}, \quad \forall i, j, k, r \in\{1, \ldots, n\}
$$

The free energy $\mathrm{F}$ is the promised function whose third derivatives with respect to the $\mathrm{t}_{0, \alpha}$ at any point define a commutative, associative algebra [9]. 
In this work we consider the equation of associativity for $n=3$ case with an metric such that $\eta_{11} \neq 0$

$$
\eta=\left(\begin{array}{lll}
1 & 0 & 0 \\
0 & 0 & 1 \\
0 & 1 & 0
\end{array}\right)
$$

When the metric is as follows (1) the interval is denoted:

$$
d s^{2}=g_{\mu \nu} d x^{\mu} d x^{\nu}=g_{11} d x^{1} d x^{1}+g_{23} d x^{2} d x^{3}+g_{32} d x^{3} d x^{2}=d x d x+d y d z+d z d y=d x^{2}+2 d y d z
$$

The equations of associativity for $n=3$ case with an metric such that $\eta_{11} \neq 0$ (1) given by:

$$
\frac{\partial^{3} F}{\partial x \partial x \partial y} \frac{\partial^{3} F}{\partial t \partial t \partial y}+\frac{\partial^{3} F}{\partial x \partial x \partial x} \frac{\partial^{3} F}{\partial t \partial t \partial t}=\frac{\partial^{3} F}{\partial t \partial x \partial y} \frac{\partial^{3} F}{\partial x \partial t \partial y}+\frac{\partial^{3} F}{\partial t \partial x \partial x} \frac{\partial^{3} F}{\partial x \partial t \partial t}
$$

where $F$ is a prepotential and have the following form:

$$
F(y, x, t)=\frac{1}{6} y^{3}+y x t+f(x, t) .
$$

For these cases the equations of associativity reduce to the following nonlinear equations of the third order for a function $f=f(x, t))$ of two independent variables $[7,8,10]$ :

$$
f_{x x x} f_{t t t}-f_{x x t} f_{x t t}=1,
$$

Let us introduce new variables $a, b, c$ as follows $[7,8]$ :

$$
a=f_{x x x}, \quad b=f_{x x t}, \quad c=f_{x t t} .
$$

In the above variables the equation (2) can be rewritten as a system of three equations in the following way $[7,8]$ :

$$
\left\{\begin{array}{c}
a_{t}=b_{x}, \\
b_{t}=c_{x}, \\
c_{t}=\left(\frac{(1+b c)}{a}\right)_{x}
\end{array}\right.
$$

The Lax pair for the system (3) is given by $[7,8]$ :

$$
\begin{aligned}
& \Psi_{x}=\lambda U \Psi, \\
& \Psi_{t}=\lambda V \Psi,
\end{aligned}
$$

where $U$ is given by $[7,8]$ :

$$
U=\left(\begin{array}{lll}
0 & 1 & 0 \\
0 & b & a \\
1 & c & b
\end{array}\right)
$$

and $V$ is given by $[7,8]$ :

$$
V=\left(\begin{array}{ccc}
0 & 0 & 1 \\
1 & c & b \\
0 & \frac{(1+b c)}{a} & c
\end{array}\right)
$$


The compatibility condition for the system (4) is given by:

$$
\begin{aligned}
& U_{t}=V_{x}, \\
& {[U, V]=0 .}
\end{aligned}
$$

The solution to a hierarchy for $N=1$ case with an metric $\eta_{11} \neq 0$ corresponds to the system of equations (3). The solution to a hierarchy for $\mathrm{n}=3$ and $N=2$ case with an antidiagonal metric $\eta$ when $\mathrm{V}_{0} \neq 0$ is given in the work [11]. In the paper $[12,13]$ considers the hierarchy for $\mathrm{n}=3$ and $\mathrm{N}=2$ case with an antidiagonal metric $\eta$ when $\mathrm{V}_{0}=0$. In this article we consider a hierarchy for $\mathrm{n}=3$ and $\mathrm{N}=2$ case with an metric $\eta_{11} \neq 0$ for $\mathrm{V}_{0}=0$.

Consider the Lax pair for $N=2$ case when $V_{0}=0$

$$
\begin{aligned}
& \Psi_{x}=\lambda U \Psi, \\
& \Psi_{t}=\left(\lambda^{2} V_{2}+\lambda V_{1}\right) \Psi=V \Psi
\end{aligned}
$$

The compatibility condition of (4) is given by:

$$
\lambda U_{t}-V_{x}+\lambda[U, V]=0 .
$$

Collecting terms in (6) by the powers of $\lambda$ we obtain

$$
\begin{aligned}
& \lambda^{3}:\left[U, V_{2}\right]=0, \\
& \lambda^{2}:-V_{2 x}+\left[U, V_{1}\right]=0, \\
& \lambda^{1}: U_{t}-V_{1 x}=0 .
\end{aligned}
$$

The values of the matrix $\mathrm{U}$ are given by in the equation (5). Denote the matrices $V_{2}, V_{1}$ as follows:

$$
V_{2}=\left(\begin{array}{lll}
z_{11} & z_{12} & z_{13} \\
z_{21} & z_{22} & z_{23} \\
z_{31} & z_{32} & z_{33}
\end{array}\right), \quad V_{1}=\left(\begin{array}{lll}
y_{11} & y_{12} & y_{13} \\
y_{21} & y_{22} & y_{23} \\
y_{31} & y_{32} & y_{33}
\end{array}\right) .
$$

using (7), we obtain the following relations:

$$
\begin{aligned}
& z_{21}=z_{13}, \\
& z_{22}=z_{11}+b z_{12}+c z_{13}, \\
& z_{23}=a z_{12}+b z_{13}, \\
& z_{31}=z_{12}, \\
& z_{32}=c z_{12}+\frac{1+b c}{a} z_{13}, \\
& z_{33}=z_{22} .
\end{aligned}
$$

Thus the matrix $V_{2}$ has the form

$$
V_{2}=\left(\begin{array}{ccc} 
& & \\
z_{11} & z_{12} & z_{13} \\
z_{13} & z_{11}+b z_{12}+c z_{13} & a z_{12}+b z_{13} \\
z_{12} & c z_{12}+\frac{1+b c}{a} z_{13} & z_{11}+b z_{12}+c z_{13}
\end{array}\right) .
$$


Hence, only $z_{11}, z_{12}, z_{13}$ are independent elements of $V_{2}$, and the other elements can be written in terms of them. Now let us find the elements of $V_{1}$. To do so we use the equation (8)

Hence, dependent elements of $V_{1}$ are given by:

$$
\begin{aligned}
& y_{21}=z_{11 x}+y_{13}, \\
& y_{22}=z_{12 x}+y_{11}+b y_{12}+c y_{13}, \\
& y_{23}=z_{13 x}+a y_{12}+b y_{13}, \\
& a y_{31}=2 z_{13 x}-b z_{11 x}+a y_{12}, \\
& a y_{32}=2 z_{11 x}+b_{x} z_{12}+b z_{12 x}+c_{x} z_{13}+2 c z_{13 x}+y_{13}+a c y_{12}+b c y_{13}, \\
& a y_{33}=a_{x} z_{12}+2 a z_{12 x}+b_{x} z_{13}+b z_{13 x}+a y_{11}+a b y_{12}+a c y_{13} .
\end{aligned}
$$

By substituting the values for $z_{31 x}, z_{32 x}, z_{33 x}$ we have a system

$$
\begin{aligned}
& 3 z_{12 x}-c z_{11 x}-\frac{b}{a} z_{13 x}+\frac{b^{2}}{a} z_{11 x}+\frac{a_{x}}{a} z_{12}+\frac{b_{x}}{a} z_{13}=0, \\
& c_{x} z_{12}+2 c z_{12 x}+\left(\frac{1+b c}{a}\right)_{x} z_{13}+\frac{3+2 b c}{a} z_{13 x}-\frac{b}{a} z_{11 x}+\frac{c a_{x}}{a} z_{12}+\frac{c b_{x}}{a} z_{13}=0, \\
& 3 z_{11 x}+2 b_{x} z_{12}+2 b z_{12 x}+2 c_{x} z_{13}+2 c z_{13 x}=0
\end{aligned}
$$

Now let us use the equation (9), writing a new system with equations for $a_{t}, b_{t}, c_{t}$ yields

$$
\begin{aligned}
& a_{t}=y_{23 x}, \\
& b_{t}=y_{22 x}, \\
& b_{t}=y_{33 x}, \\
& c_{t}=y_{32 x} .
\end{aligned}
$$

Using necessary terms in the system (10)-(15) in (19)-(22), we have

$a_{t}=z_{13 x x}+a y_{12 x}+a_{x} y_{12}+b_{x} y_{13}+b y_{13 x}$,

$b_{t}=z_{12 x x}+y_{11 x}+b_{x} y_{12}+b y_{12 x}+c_{x} y_{13}+c y_{13 x}$,

$b_{t}=\frac{a a_{x x}-a_{x}^{2}}{a^{2}} z_{12}+\frac{a_{x}}{a} z_{12 x}+2 z_{12 x x}+\frac{a b_{x x}-a_{x} b_{x}}{a^{2}} z_{13}+\frac{b_{x}}{a} z_{13 x}+\frac{a b_{x}-b a_{x}}{a^{2}} z_{13 x}+\frac{b}{a} z_{13 x x}$

$+y_{11 x}+b_{x} y_{12}+b y_{12 x}+c_{x} y_{13}+c y_{13 x}$,

$c_{t}=\frac{2}{a} z_{11 x x}-\frac{2}{a^{2}} z_{11 x}+\frac{b_{x x} a-a_{x} b_{x}}{a^{2}} z_{12}+\frac{b_{x}}{a} z_{12 x}+\frac{b}{a} z_{12 x x}+\frac{a b_{x}-b a_{x}}{a^{2}} z_{12 x}+\frac{c_{x}}{a} z_{13 x}+\frac{a c_{x x}-a_{x} c_{x}}{a^{2}} z_{13}+$

$\frac{2 a c_{x}-2 c a_{x}}{a^{2}} z_{13 x}+\frac{2 c}{a} z_{13 x x}+c_{x} y_{12}+c y_{12 x}+\frac{1+b c}{a} y_{13 x}+\left(\frac{1+b c}{a}\right)_{x} y_{13}$

Since $z_{11 x x}=0$ we have

$$
z_{13 x x}=\frac{1}{a} z_{13 x}+\frac{a b_{x}-b a_{x}}{2 a} z_{11 x}
$$

Equating the RHSs of the equations $(24,25)$ for $b_{t}$ above, we obtain the following equation: 


$$
\frac{a a_{x x}-a_{x}^{2}}{a^{2}} z_{12}+\frac{a_{x}}{a} z_{12 x}+z_{12 x x}+\frac{a b_{x x}-a_{x} b_{x}}{a^{2}} z_{13}+\frac{b_{x}}{a} z_{13 x}+\frac{a b_{x}-b a_{x}}{a^{2}} z_{13 x}+\frac{b}{a} z_{13 x x}=0 .
$$

From equation (28) we express $z_{12 x x}$ and obtain the following equation:

$$
z_{12 x x}=\frac{a_{x}^{2}-a a_{x x}}{a^{2}} z_{12}-\frac{a_{x}}{a} z_{12 x}+\frac{a_{x} b_{x}-a b_{x x}}{a^{2}} z_{13}-\frac{b_{x}}{a} z_{13 x}+\frac{b a_{x}-a b_{x}}{a^{2}} z_{13 x}-\frac{b}{a^{2}} z_{13 x}+\frac{b^{2} a_{x}-a b b_{x}}{2 a^{2}} z_{11 x}
$$

From equation (18) we express $z_{11 x}$ which is given by:

$$
z_{11 x}=-\frac{1}{3}\left(2 b_{x} z_{12}+2 b z_{12 x}+2 c_{x} z_{13}+2 c z_{13 x}\right) .
$$

We plug $z_{11 x}$ in (30) into (16) and (17) and obtain the following equations, respectively

$$
\begin{aligned}
& \left(2 a c b_{x}-2 b^{2} b_{x}+3 a_{x}\right) z_{12}+\left(9 a+2 a c b-2 b^{3}\right) z_{12 x}+\left(2 a c c_{x}-2 b^{2} c_{x}+3 b_{x}\right) z_{13}+\left(2 a c^{2}-2 b^{2} c-3 b\right) z_{13 x}=0 \\
& \left(3 a^{2} c_{x}+2 a b b_{x}+3 a c a_{x}\right) z_{12}+\left(6 a^{2} c+2 a b^{2}\right) z_{12 x}+\left(6 a c b_{x}+5 a b c_{x}-3 a_{x}-3 b c a_{x}\right) z_{13}+(9 a+8 a b c) z_{13 x}=0
\end{aligned}
$$

Now we express $z_{12 x}$ in (31) to obtain

$$
z_{12 x}=\frac{1}{\left(2 b^{3}-9 a-2 a b c\right)}\left\{\left(2 a c b_{x}-2 b^{2} b_{x}+3 a_{x}\right) z_{12}+\left(2 a c c_{x}-2 b^{2} c_{x}+3 b_{x}\right) z_{13}+\left(2 a c^{2}-2 b^{2} c-3 b\right) z_{13 x}\right\}
$$

Now we express $z_{13 x}$ in (32) to obtain

$$
z_{13 x}=-\frac{1}{(9 a+8 a b c)}\left\{\left(3 a^{2} c_{x}+2 a b b_{x}+3 a c a_{x}\right) z_{12}+\left(6 a^{2} c+2 a b^{2}\right) z_{12 x}+\left(6 a c b_{x}+5 a b c_{x}-3 a_{x}-3 b c a_{x}\right) z_{13}\right\}
$$

The solution to a hierarchy for $n=3$ and $\mathrm{N}=2$ case with an metric $\eta_{11} \neq 0$ when $\mathrm{V}_{0}=0$ the system is given by (3) corresponds to the system of above equations (23), (24), (26), where values $\mathrm{z}_{12 \mathrm{x}}, \mathrm{z}_{12 \mathrm{xx}}, \mathrm{z}_{13 \mathrm{x}}$ and $\mathrm{z}_{13 \mathrm{xx}}$ from Eqs. (33), (29), (34), (27).

So, in this work we considered the hierarchy of the associativity equation for $n=3$ and $\mathrm{N}=2$ case with an metric $\eta_{11} \neq 0$ when $\mathrm{V}_{0}=0$. The equation of associativity for $n=3$ case with an metric $\eta_{11} \neq 0$ was written in general form. So, we considered of some cases of hierarchy for $n=3$ and $\mathrm{N}=2$ case with an metric $\eta_{11} \neq 0$ when $\mathrm{V}_{0}=0$ of the associativity equations.

Lax pairs for the system of three equations, that contains the equation of associativity are written to find the hierarchy of associativity equation. Using the compatibility condition are found the relations between the matrices $\mathrm{U}, \mathrm{V}_{2}, \mathrm{~V}_{1}$.

Thus, we obtained the elements of the matrices $\mathrm{V}_{2}, \mathrm{~V}_{1}$ for this described case. The elements of matrix $\mathrm{V}_{2}$ are found with the expression of $\mathrm{z}_{\mathrm{ij}}$ and independent and dependent variables for the matrix $\mathrm{V}_{2}$.

It was found, that only $\mathrm{z}_{11}, \mathrm{z}_{12}, \mathrm{z}_{13}$ are independent elements of $\mathrm{V}_{2}$, and the other elements can be written in terms of them. Also solving elements of matrix $V_{1}$ expressed through $y_{i j}$ and independent and dependent variables for the matrix $\mathrm{V}_{1}$.

It is found, that $\mathrm{y}_{11}, \mathrm{y}_{12}, \mathrm{y}_{13}$ are independent elements of $\mathrm{V}_{1}$, and the other elements can be written in terms of them and $\mathrm{z}_{11}, \mathrm{z}_{12}, \mathrm{z}_{13}$. We accepted that elements of matrix $\mathrm{V}_{0}$ are zero.

It is found the relationship between the elements $a_{t}, b_{t}, c_{t}$ and $y_{i j x}$ of the matrices $U_{t}, V_{1 x}$. So, expressed are variables $a_{t}, b_{t}, c_{t}$ of three equations are written with the help of matrix elements $z_{12}, z_{13}, y_{12}, y_{13}$.

\section{References:}

1 Dijkgraaf R., Verlinde H.L., Verlinde E.P. Notes on topological string theory and $2 d$ quantum gravity // IASSNSHEP-90-80

2 Witten E. On the structure of the topological phase of two-dimensional gravity // Nucl. Phys. B340 - 1990. - P. 281332 Verlinde E., Verlinde H. A Solution of two dimensional topological quantum gravity // preprint IASSNS-HEP-90/40, PUPT-1176 - 1990

4 Dijkgraaf R., Witten E. // Nucl. Phys. B342 - 1990. - 486 p.

5 Dijkgraaf R., Verlinde E., Verlinde H. Loop equations and Virasoro constraints in Non-Perturbative $2 D$ Quantum Gravity // preprint PUPT-1184 -Nucl. Phys. B to be publishe 
6 Strachan Ian A.B, Stedman R. Generalized Legendre Transformations and Symmetries of The WDVV equations // Journal of Physics A: Math. Theor. 50 - 2017. - Volume 50 -№ 9

7 Mokhov O.I., Ferapontov Y.V. The associativity equations for two-dimensional topological field theory as integrable hamiltonian non-diagonalizable systems of hydrodynamic type // Functional analysis and its applications- 30 (3),1996. - P. 62-72

8 Mokhov O.I. Symplectic and poisson geometry on loop spaces of manifolds and nonlinear equations // Translations of the American Mathematical Society-Series 2170 - 1995. - 121-152, arXiv:hep-th/9503076

9 Witten E. Two-dimensional gravity and intersection theory on moduli space // Surv. Diff. Geom. 1- 1991. - P. 243-310

10 Dubrovin B.A. Geometry of 2D topological field theories, Springer Lecture Notes in Math. 1620, 120-348, 1996. [arXiv:hep-th/9407018]

11 Zhadyranova A.A., Myrzakul Zh.R., Anuarbekova Y.Ye. Hierarchy of WDVV associativity equations for $n=3$ case and $N=2$ when $V_{0} \neq 0 / /$ Bulletin of L.N. Gumilyov Eurasian National University - 4(125) - 2018. - P. 79-85

12 Zhadyranova A.A., Anuarbekova Y.Ye. Hierarchy of WDVV associativity equations for $n=3$ case and $N=2$ when $V_{0}=0 / /$ Bulletin of L.N. Gumilyov Eurasian National University - 3(128) - 2019. - P. 60-66

13 Zhadyranova A.A. Hierarchy of WDVV associativity equations for $n=3$ and $N=2$ case when $V_{0}=0$ with new system $a_{t}, b_{t}, c_{t} / /$ News of the National Academy of Sciences of the Republic of Kazakhstan. Physical-mathematical series. https://doi.org/10.32014/2019.2518-1726.39-4(326) - 2019-P. 14-21

МРНТИ 29.05.23; 29.05.29; 29.05.41

DOI: https://doi.org/10.51889/2020-1.1728-7901.35 УДК 539.1

\author{
Д.М. Зазулин ${ }^{1,2}$, С.Е. Кемелжанова ${ }^{1}$, П.Д. Эзау ${ }^{3}$ \\ ${ }^{1}$ Казахский Национальный Университет имени аль-Фараби, г. Алматы, Казахстан \\ ${ }^{2}$ Институт Ядерной Физики, г. Алматы, Казахстан \\ ${ }^{3}$ Петербургский Институт Ядерной Физики, Россия

\section{ПРИМЕНЕНИЕ ГЕОМЕТРОТЕРМОДИНАМИКИ К СИСТЕМЕ С НУЛЕВЫМ ЗВУКОМ ОПИСАННОЙ МЕТОДОМ ГОЛОГРАФИЧЕСКИХ ДУАЛЬНОСТЕЙ}

\title{
Аннотация
}

В рамках метода геометротермодинамики в настоящей работе исследованы свойства равновесного многообразия системы с нулевым звуком, предсказанной методом голографических дуальностей. Получены результаты инвариантные относительно преобразований Лежандра, т.е. независимые от выбора термодинамического потенциала. Для рассматриваемой системы рассчитаны соответствующие метрики и скалярные кривизны, а также описаны их свойства. С помощью голографического подхода в работе был обнаружен новый тип квантовой жидкости. Теплоемкость, полученной в этой работе жидкости, при низких температурах зависит от температуры $\sim \mathrm{T}^{6}$. В качестве термодинамического потенциала бралась энтропия, зависящая от температуры и барионной плотности. Получены 3-мерные графики, на которых хорошо видно, при каких значениях термодинамических переменных скалярные кривизны стремятся к бесконечности или к нулю, что указывает на возможные фазовые переходы и на возможную компенсацию взаимодействий квантовыми эффектами соответственно.

Показано, что оба варианта метрик в данном случае приводят к одному и тому же выводу относительно расположения линий возможных фазовых переходов в рассмотренной голографической системе с нулевым звуком.

Ключевые слова: геометротермодинамика, преобразования Лежандра, метрический тензор, скалярная кривизна, голографические дуальности, нулевой звук.

\author{
Аңдатпа \\ Д.М. Зазулин ${ }^{1,2}$, С.Е. Кемелжанова, П.Д. Эзау \\ ${ }^{1}$ әл-Фараби атындавы Қазақ Ұлттық Университеті, Алматы қ., Қазақстан \\ 2 Ядрольқ Физика институты, Алматы қ., Қазақстан \\ ${ }^{3}$ Петербург ядрольқ физика институты, Россия
}

\section{ГОЛОГРАФИЯЛЫК ДУАЛЬДІК ӘДІСПЕН СИПАТТАЛҒАН НӨЛДІК ДЫБЫСЫ БАР ЖҮЙЕГЕ ГЕОМЕТРИЯЛЫҚ ТЕРМОДИНАМИКАНЫ ҚОЛДАНУ}

Термодинамика геометриясы әдісі аясында бұл жұмыста голографиялық дуальдік әдіспен болжанған нөлдік дыбысы бар жүйенің тепе-теңдік күйдегі алуан түрлілігінің қасиеттері зерттелді. Лежандр түрлендірулеріне қатысты инвариантты нәтижелер термодинамикалық потенциалды таңдауға тәуелсіз есептелінді. Осы қарастырылып отырған жүйе үшін тиісті метрикалар мен скалярлы қисықтар есептелініп, қасиеттері сипатталды. 